Original Research Paper

\title{
The Grammaticalization of the Spanish Complement-taking Verb without a Complementizer
}

\author{
Jiyoung Yoon \\ Department of World Languages, Literatures and Cultures, University of North Texas, Denton, USA
}

Article history

Received: 11-03-2015

Revised: 19-05-2015

Accepted: 19-05-2015

\begin{abstract}
This study examines authentic data samples taken from the Corpus de Referencia del Español Actual (CREA) in order to uncover any semantic trends that can be commonly observed in verbs taking a sentential complement without the complementizer que in Spanish. In doing so, special attention is given to the grammaticalization process that can account for epistemic fragments in which the semantic meaning of the verb becomes attenuated and where the main verb alone without a complementizer functions like an adverbial phrase. Four semantic groups of verbs with a zero complementizer are analyzed: (i) Verbs of cognition/mental act (e.g., creer 'think'); (ii) verbs of communication (e.g., decir 'say'); (iii) verbs of volition and desire (e.g., esperar 'hope'); and iv) verbs of emotion (e.g., temer 'fear'). These verb groups allowing a zero complementizer show differences with respect to (i) the subjunctive and indicative use in the embedded clause, (ii) the formal Vs. informal registers and (iii) the use of the complement-taking verbs as a fragment/parenthetical or an epistemic marker (in order to capture the degree of grammaticalization). This study proposes that not all the verbs that allow for the omission of the complementizer undergo the same degree of grammaticalization, but the semantics of the main verb interacting with all those factors play a role in determining the likelihood of the omission and the possibility that the main verb can actually be used as a floated parenthetical with a more subjective meaning that involves a more active process of grammaticalization. It is also shown that the degree of grammaticalization differs from verb to verb, as well as from verb class to verb class.
\end{abstract}

Keywords: Spanish, Zero Complementizer, Grammaticalization, Parenthetical, Epistemic Marker

\section{Introduction}

Spanish is often described as a language in which a sentential complement normally requires the presence of the complementizer que 'that' as in (1), unlike in English (2) in which the omission of the complementizer that is optional:

(1) a. Diego sabía que tendría el apoyo. "Diego knew that he would have the support."

b. *Diego sabía Ø tendría el apoyo.
"Diego knew (that) he would have the support."

(2) Diego knew (that) he would have the support.

It has been noted in literature, however, that a full sentential complement in Spanish can appear without a complementizer just like in English, but little is known about the usages and patterns related to such an omission. Brovetto (2002) proposes that the Spanish complementizer que 'that' may be optional when, for example, the embedded proposition conveys a meaning of uncertainty or an irrealis meaning as shown in (3): 
(3) Espero (que) se solucionen pronto los problemas causados por el huracán.

"I hope (that) the problems caused by the hurricane will be solved soon."

(example taken from Brovetto (2002)

Although this observation gives us an insight into the phenomenon studied, the example in (4), taken from the CREA corpus collected by the Real Academia Española, shows that the embedded proposition does not necessarily have to convey an irrealis meaning to allow for the zero complementizer:

(4) Entonces yo digo Ø siempre me encantó. De chiquilla tenía facilidad para dibujar, en vacaciones era mi hobby.

"Then I say Ø I always loved it. Since I was little, I had the ability to draw; on vacations it was my hobby."

(CREA, oral data, Costa Rica)

The main verb decir 'to say' (in yo digo 'I say') has a sentential complement that denotes a realis meaning (siempre me encantó 'I always loved it'), but the omission of the complementizer que is still possible. This leads us to think that the zero complementizer phenomenon in Spanish is more complex than one might have thought from simple observations and intuition and that more comprehensive studies tackling this topic are needed.

This study examines authentic data samples taken from the Corpus de Referencia del Español Actual (CREA) in order to uncover any semantic trends that can be commonly observed in verbs taking a sentential complement without a complementizer. In doing so, special attention will be given to the grammaticalization process that can account for epistemic/evidential/evaluative fragments (Thompson, 2002) in which the semantic meaning of the verb becomes attenuated and where the main verb alone without a complementizer functions like an adverbial phrase. Examples are given in Spanish (5) and English (6):

(5) Somos hermanas del alma, creo.

"We are sisters of the spirit [soul mates], (I) think." (CREA, oral data, México, 1999)

(6) A man would never do that. Because, number one they pick out, ..I think.. more vulnerable people. (adapted from example (18), Kärkkäinen, 2007)

In both examples (5) and (6), the verb creo and $I$ think, respectively, are interpreted as adverbial phrases such as en mi opinión/in my opinion.

What this study will show, however, is that not all the main verbs that allow for the omission of the complementizer que are undergoing the same degree of the grammaticalization process, but that the semantics of the main verb plays a certain role in determining the likelihood that the main verb can actually be used as an epistemic marker with a more subjective meaning involving a more active process of grammaticalization (cf. Traugott, 1995). At the same time, it will be shown that Spanish and English exhibit different patterns and usages of the zero complementizer, although some similarities are also found between the two languages.

In the next section, I will briefly present the concept of grammaticalization. Section 3 examines some possible factors favoring the deletion of the complementizer in Spanish which have been discussed in some of the previous work. Section 4 presents sample data from the CREA and analyzes various conditions and contexts that are related to the omission of the complementizer, such as main verb types, formal and informal registers, a parenthetical use of the complement-taking verb without a complementizer and the subjunctive Vs. indicative mood in the embedded clause. Finally, section 5 summarizes the main findings of this study and suggests possible direction for future research.

\section{The Concept of Grammaticalization}

Grammaticalization is the set of semantic and structural processes, by which constructions involving particular lexical items are used with increasing frequency and gradually become new grammatical constructions over time (Bybee et al., 1994; Traugott, 2003; Torres-Cacoullos, 2011; Torres-Cacoullos and Walker, 2011). For instance, it is well known that the phonetic reduction of the future expression (BE) going to to gonna indicates decreased analyzability (that is, increased autonomy) of a new single unit gonna over time (Bybee, 2006).

Sentential complement-taking [subject-verb] constructions in English without the complementizer that have also drawn much attention from researchers as structures in which a grammaticalization process is involved. A collocation-based perspective maintains that the frequent collocations of main-clause subjects and verbs (e.g., I think, I believe and I guess) without complementizers have been reanalyzed as discourse markers that are interpreted as epistemic adverbials instead of functioning as main clauses (Thompson and Mulac, 1991). In this context, the concept of the complementation becomes blurred since "the complement overrides the main clause and the main clause is there to provide speaker stance towards the assessments, claims, counterclaims and proposals" (Thompson, 2002). This view is known as a fragment analysis in which the subject (which is typically the firstperson singular) and the complement-taking matrix verb together function like an epistemic/evaluative adverbial fragment and a floated parenthetical (e.g., in my opinion 
for I think) rather than as a main verb governing an embedded sentence as its direct object complement (Thompson, 2002):

(7) I can't even believe $\varnothing$ I just said that. (example taken from the Quebec English Corpus in Poplack et al., 2006)

Although primary attention has been drawn mainly to verbs of cognition or mental act, some other frequencybased approaches (Poplack et al., 2006) also identify main-clause verb types in the complementizer construction. They found that think, know and say account for $63 \%$ of all the data while guess, tell, remember, find and realize account for $19 \%$. Interestingly enough, however, their findings suggest that there is no correlation between token frequency and the rate of that (Vs. zero complementizer). In other words, frequency is not necessarily a decisive factor that triggers more use of the zero complementizer with those verb types (see discussions in Gonzálvez-García (2014) for arguments against a fragment analysis in support of the lack of correlation between frequency and zero complementizer).

On the other hand, multivariate analyses of factors favoring the zero complement tackle all the possible factors (in addition to the semantics of the matrix verbs) that can contribute to the grammaticalization process in which the omission of the complementizer occurs (Torres-Cacoullos and Walker, 2011). Some of the common factors contributing to the omission of the complementizer are, for example, (i) matrix clause subjects such as $I$ or you; (ii) a co-referential pronoun between the complement clause and the matrix clause subject (e.g., I think I got it right) (Posio (2011; 2013; 2014) for the detailed discussions about the expression of the first (and the second) person singular subject pronouns in Spanish in relation to verb semantics and grammaticalization); (iii) the absence of intervening elements between the matrix and complement clause (e.g., I remember my mother used to [...] Vs. I remember on Sunday, my mother used to [...]); and, iv) the absence of main-clause adverbials (e.g., I still think $\varnothing$ he is innocent Vs. I think $\varnothing$ he is innocent). Based on their findings, Torres-Cacoullos and Walker (2011) suggest that the omission of the complementizer that occurs when there is less semantic content in the main clause and the two clauses (main and embedded) together act more like a single proposition.

Given that I have presented some of the approaches to the zero complementizer phenomenton in English in relation to grammaticalization, frequency and variable analyses, in the next section, I will focus on the omission of the complementzier que in Spanish and its differences-and similarities-with what has been discussed in some of these previous studies.

\section{Omission of the Complementizer que in Spanish}

It has been noted that there are some differences between the zero complementation in Spanish and English (Llinàs-Grau and Fernández-Sánchez, 2011). In Spanish, some researchers mention that it is normally the subjunctive mood of the embedded clause that allows que to be omitted (Brovetto, 2002; Llinàs-Grau and Fernández-Sánchez, 2011):

(8) Deseamos (que) tenga usted una we wish (that) have-SUBJ you a feliz estancia.

happy stay

"We wish you a nice stay"

(example [19] from Llinàs-Grau and

Fernández-Sánchez, 2011)

But at the same time, there has been an observation that the omission of que can occur if the indicative mood of the embedded clause conveys an irrealis meaning in the form of conditional or future tenses (Brovetto, 2002):

(9) Dijo (que) llegaría tarde a la

he-said (that) he-arrive-IND-Cond. late to the reunión.

meeting

"He said (that) (he) would be late to the meeting."

(example [3b] taken from Brovetto (2002))

Brovetto (2002) hypothesizes that one can then expect to find the omission of que with verbs in the complement clause in the subjunctive mood rather than in the indicative mood (although the omission may be still possible in some cases) because the subjunctive mood is associated with unreality or possibility. Interestingly, she notes that the absence of que is not usually possible with verbs of utterance such as decir 'say' or with factive verbs such as confesar 'confess', admitir 'admit' and jurar 'swear' if the embedded clause denotes a realis meaning, but she also mentions that with these types of verbs, the omission can occur if the indicative mood of the embedded clause conveys an irrealis meaning as in (9).

As will be observed in the following section, however, many examples found in the CREA corpus show that it is not necessarily the subjunctive mood, or the irrealis meaning conveyed by the indicative mood, that triggers the omission of the complementizer in Spanish: 
(10) De Tschaikovsky, el dúo de "Vodemon" y "Yolanta" en la ópera de este último título, que confieso $\varnothing$ escuché por primera vez y que es reflejo de la tensión [...].

"The duet of "Vodemon" and "Yolanta" of Tschaikovsky in the opera of this last title, which (I) confess $\varnothing$ I heard for the first time and that it is reflection of the tension [...]."

(CREA, newspaper/magazine, Spain, 1988)

Example (10) shows that the embedded sentence escuché por primera vez y que es reflejo de la tensión 'I heard for the first time and that it is reflection of the tension' indeed denotes a realis meaning, but the omission of the complementizer que is still possible with the matrix verb confesar 'confess'. I will show in the following section that the CREA data analysis suggests that it is not necessarily the mood or the irrealis meaning of the embedded clause itself, but certain classes of main verbs that tend to allow for the omission of the complementizer and depending on which verb type, either the subjunctive or indicative mood can appear in constructions with the zero complementizer.

In fact, the wide range of semantic types of matrix verbs in Spanish has been noted as one of the differences between Spanish and English in some literature. The semantic group of verbs that allow the zero complementizer in Spanish is not limited to the so-called bridge verbs as in English, but includes many other types of predicates. For the matrix verbs that can typically occur without a complementizer, the previous studies usually mention verbs of propositional attitude such as the 'suppose' class of verbs (e.g., suponer 'suppose,' dudar 'doubt,' parecer 'seem'), emotion verbs such as the 'lament' class of verbs (e.g., lamentar 'lament,' preocuparse 'be worried,' alegrarse 'be glad,' sentir 'be sorry') and verbs of volition and desire (e.g., querer 'want,' desear 'desire,' esperar 'hope'), all of which usually take the subjunctive in their embedded clause (Delbecque and Lamiroy, 1999; Brovetto, 2002; Llinàs-Grau and Fernández-Sánchez, 2011) (The list of verbs also mostly coincides with the semantic groups of verbs taking infinitival complement constructions in Spanish, proposed in Yoon (2004)):

(11) Ellas, supongo, estaban deslumbradas ante una persona... una mujer que hacía lo que le venía en gana

"They were, (I) guess, dazzled before a person... a woman who was doing what she wanted to do." (CREA, testimonial, Mexico, 2002)

(12) Lamento (que) no estés

I-lament (that) not you-be-SUBJ-2PS

contenta con tu trabajo.

happy with your job
“(I) lament (that) you are not happy with your job.' (example taken from Torrego (1983) cited in Brovetto (2002))

(13) La imagen de Cristo es una copia del famoso escultor danés Thorvaldsen, que espero $\varnothing$ le guste. "The image of Christ is a copy of the famous Danish sculptor Thorvaldsen, which (I) hope $\varnothing$ you like."

(CREA, novel, Costa Rica, 1996)

The fact that the omission of the complementizer in Spanish relies heavily on the semantics of the matrix verb is different from English. These semantic classes of the matrix verb in Spanish are an important basis on which the CREA data samples of this study are drawn, but as we will see, one extra verb class will be added to the list, namely, verbs of communication such as decir 'say' and confesar 'confess', based on the data samples found in the CREA:

(14) Por eso yo digo Ø yo estoy en la tesis de Otón Solís y de Eduardo Lizano, que son liberacionistas. "For that reason I say $\varnothing$ I am in the thesis of Otón Solís and of Eduardo Lizaono, who are women's libbers."

(CREA, oral data, Costa Rica)

It has also regularly been noted that the omission of the complementizer in Spanish occurs more often in formal contexts than in informal ones, unlike in English (Demonte and Fernández-Soriano, 2009). This is an interesting observation since in English, the omission of the complementizer typically occurs in more informal settings:

(15) Le ruego Ø lo tenga

to you I beg it have-SUBJ

en cuenta para el fututo.

into account for the future

"(I) beg you $\varnothing$ you take this into account for the future."

(Demonte and Fernández-Soriano (2009), example from footnote 16)

The following section will show, however, that the zero complementation in Spanish actually occurs regularly in informal contexts too, but one may find more omission in formal contexts especially with the volition verb type such as rogar 'beg' and suplicar 'request, beg'. Other verb types such as verbs of cognition (e.g., creer 'think'), verbs of emotion (e.g., temer 'be afraid') and verbs of communication (e.g., decir 'say') appear to allow the omission of the complementizer regardless of whether the register is formal or informal: 
(16) Nadie se dio cuenta de que había jugado sin fondos, cosa que, supongo, hubiera escandalizado cuando menos a mis primos.

"Nobody realized that he played without funds, which, (I) suppose, would have shocked my cousins." (CREA, novel, México, 1979)

(17) Vivir para ser ejemplo, para cosechar alegrías y abrazos de personas que de todo corazón te dicen $\varnothing$ te quiero $[. .$.

"To live in order to be a role model, in order to gain happiness and hugs from people who say to you from the heart (that) I love you [...]"

(CREA, essay-blog EFÍMERO, Costa Rica, 2003)

Example (16) represents an informal register (in a novel) in which a first person narrates a story in an informal tone (as shown in the phrase cosa que 'a thing that'), but the complementizer is not used, as the verb supongo 'I suppose' here functions like an epistemic marker. In (17), the informal register is indicated in the use of the clitic pronoun te 'to you-informal' in te dicen 'they say to you', as we observe again the omission of the complementizer.

So far, we have observed some interesting differences of Spanish and English in regard to the omission of the complementizer, but in fact, there are still some similarities between the two languages. For instance, just like in English, sentential complements without the complementizer que in Spanish commonly occur with the first person subject of the matrix verb (cf. Traugott, 1995; Torres-Cacoullos and Walker, 2011).

(18) Y yo creo, estoy convencida que [...] la labor de estos hombres, como en el caso de Omar Dengo, estuvo estrechamente ligada en su origen.

"And I think, I am convinced that [...] the labor of these men, just like in the case of Omar Dengo, was closely linked to their origin."

(CREA, oral data, Costa Rica)

A similar tendency is found in English: Among the three highest-frequency lexical types (think, know and say), think is mainly restricted to first-person singular present tense (Torres-Cacoullos and Walker, 2011). In fact, I mentioned in the previous section that a collocation approach to zero complementation postulates that certain frequent collocations of mainclause first-person singular subjects and verbs in English (e.g., I guess, I think) function as epistemic adverbials and parentheticals (i.e., I guess and I think interpreted as 'in my opinion') rather than as main clauses taking a complement clause (Thompson and Mulac, 1991). The same seems to hold true for Spanish where one finds the omission of the complementizer with the first-person singular subjects more often than other types of subjects (Travis 2006; Vázquez Rozas 2006; Posio, 2011; 2013; 2014). For instance, yo creo/creo '(I) think' and yo digo/digo '(I) say' seem to have been re-analyzed as epistemic markers that may serve a multitude of meta-discoursal functions, such as hedging the information provided in the complement clause. They can occur sentenceinitially, medially between pauses and sentencefinally, just like adverbs that can freely occur in various syntactic positions in a sentence.

The following section, based on the observations of differences and similarities delineated so far, will provide a more detailed analysis of the zero complement-taking verbs in Spanish. In doing so, special attention will be given to (i) the semantic types of the matrix verbs; (ii) the irrealis Vs. realis meaning of the embedded sentence, that is, whether the subjunctive (irrealis meaning) is indeed the preferred mood of choice for the zero complementizer; (iii) the formal Vs. informal registers (to see whether or not the formal context is indeed a preferred factor contributing to the omission of the complementizer; and (iv) the use of the complementtaking verbs without complementizer as a fragment or an epistemic marker (in order to capture the degree of grammaticalization). I will show that not all of the observations made in the previous studies necessarily represent all the data samples collected from the CREA database, which, therefore, warrants some revision of the hypotheses regarding the omission of the complementizer in Spanish.

\section{The Semantics of the Main Verbs and the Omission of the Complementizer}

This section analyzes the authentic data sample drawn from the CREA corpus, giving special attention to the semantics of the matrix verbs. As mentioned in the previous section, the semantics of the matrix verbs in Spanish include a wider variety of verb types than in English. This study, based on previous studies, analyzes four semantic groups of verbs that allow the zero complementizer: (i) Verbs of cognition/mental act (creer 'think, believe', pensar 'think' and suponer 'guess'); (ii) verbs of communication (decir 'say' and confesar 'confess'); (iii) verbs of volition and desire (esperar 'hope', rogar 'beg', desear 'desire', pedir 'ask', suplicar 'request, beg', solicitar 'request' and recomendar 'recommend'); and (iv) verbs of emotion (lamentar 'lament' and temer 'fear') (Many of these verbs are those verbs that have often been mentioned in the previous studies as typical verbs taking a zero complementizer in Spanish (Brovetto, 2002; Travis, 2006; Vázquez Rozas, 2006)). 
The sample data extracted from the CREA are comprised of verbs in the present tense conjugated mostly for first person singular subjects, as one expects to find more zero complementation with first person singular subjects. Although the collected data were not subject to fine-grained statistical analysis, the sample data that were included in the figures were collected from the entire country selected when the CREA allowed for the retrieval of all the examples (for example, all the data from Costa Rica and Mexico that have a construction containing a string of 'creo 'I think' $+\varnothing+$ finite complement clause') in order to find the general patterns of the omission (In the case of communication verbs, there were too many examples found in a particular dataset and they could not all be retrieved, so the sample set was narrowed down to particular genres (such as 'newspaper/magazine' and 'oral') taking into account both formal and informal registers). The only verb group that included other country (Spain) in its figures is emotion verbs in which not enough data were found in the dataset of Costa Rica and Mexico only. Note that although the figures themselves are limited to the particular datasets, illustrated examples also include another country as well. Given that the main purpose of this study is to observe and find the general tendency of the omission of the complementizer in Spanish, no particular claims will be made in regards to frequency (at least in a statistical sense) or dialectal variations.

\section{Verbs of Cognition/Mental Act}

Data for three cognition verbs that are commonly used without a complementizer were extracted mainly from the CREA database of Costa Rica (all the data) and Mexico (all the data): creo 'I believe', pienso 'I think' and supongo 'I suppose, I guess'. Table 1 shows the distribution of these three verbs that take the zero complementizer Vs. the que complementizer in the CREA corpus. It is interesting to observe that the frequency of the cognition verbs that occur in the corpus varies depending on the verb type: supongo 'I suppose, I guess' shows a higher rate of omission (30.54\%) than creo 'I think' (4.96\%) and pienso 'I think' (10.3\%).

The omission of the complementizer is commonly observed in both formal (as in all the (a) examples in [19-21]) and informal registers (all the (b) examples in [19-21]. Note that the degree of formality of register for each data sample is indicated for some of the oral data in the CREA database (but not usually for written database), which is also copied and written for the examples of oral data:

\section{(19) creo 'I think/I believe':}

a. Pero no se trata, creo, ahorita, de entrar en aspectos jurídicos, porque hubo mucha oportunidad, como bien lo dijo el Senador Aladro [...]
"But it is not, (I) think, about the issue of getting into legal aspects, because there was a lot of opportunity, just like what Senator Aladro said [...]."

(CREA, oral data, Mexico, Public session of Senate House, formality $=$ high)

b. Y yo creo, $\varnothing$ estoy convencida que en gran medida este la labor de de estos hombres, como en el caso de Omar Dengo, estuvo estrechamente ligada en su origen y en su motivación [...]

"And I think, Ø I am convinced that overall, the labor of these men, just like in the case of Omar Dengo, was closely linked in its origin and in its motivation [...]"

(CREA, oral data; face-to-face conversation, Costa Rica, formality $=$ low)

(20) pienso 'I think':

a. Yo pienso yo me sentí ofendido por dos razones bueno, en primera instancia porque yo soy Primero, porque estamos entre profesionales.

"I think $\varnothing$ I felt offended for two good reasons, first of all because I am Primero, because we are among professionals."

(CREA, oral data; face-to-face conversation/interview, Costa Rica, formality $=$ high)

b. Por razones de comodidad, decidí llevarme a la niña primero. Era más pequeña que su hermano y su carne, pienso, sería más suave.

"For reasons of convenience, I decided to take the girl first with me. She was smaller than her brother and her flesh, (I) think, would be softer."

(CREA, novel [El más violento paraíso by Alexánder Obando Bolaños, Costa Rica, 2001, formality $=$ low)

(21) supongo 'I suppose/I guess':

a. Muchas satisfacciones y lo necesario para vivir, crecer, y educar a nuestros tres hijos, una casa propia, más de 15,000 clientes que, supongo, quedaron satisfechos, $[\ldots]$

"Many pleasures and that which is necessary to live, raise and educate our three sons, our own house, more than 15,000 clients who, (I) suppose, were satisfied, $[\ldots]$ "

(CREA, newspaper/magazine, Mexico, 1996)

b. Parte de la construcción de nuestra personalidad, supongo, es la estructuración de la distancia que necesitamos que haya entre nosotros y esas imágenes. "Part of the construction of our personality, (I) suppose, is the structuralization of the distance that we need that exists between us and these images." (CREA, novel [La forma del silencio by María Luisa Puga], Mexico, 1987) 
Table 1. Distribution of cognition verbs with the zero complementizer Vs. the que complementizer in the CREA

\begin{tabular}{llll}
\hline & Zero complementizer & Que complementizer & Total \\
\hline Creo & $141(4.96 \%)$ & $2702(95.04 \%)$ & $2843(100 \%)$ \\
Pienso & $45(10.3 \%)$ & $392(89.70 \%)$ & $437(100 \%)$ \\
Supongo & $51(30.54 \%)$ & $116(69.46 \%)$ & $167(100 \%)$ \\
Total & $237(6.88 \%)$ & $3210(93.12 \%)$ & $3447(100 \%)$ \\
\hline
\end{tabular}

Cognition verbs such as creo 'I think/believe', pienso 'I think' and supongo 'I guess/suppose' that occur with the zero complementizer indeed do not appear to be restricted to formal contexts (such as a public speech, formal oral interviews and newspaper articles), but they also freely occur in informal contexts (such as an informal interview and oral conversations, narrations in a novel). Interestingly, this semantic verb group also shows many attested examples in which the matrix verbs are used as epistemic fragments and parentheticals, acquiring a more subjective meaning of evaluative/epistemic adverbs (e.g., en mi opinion 'in my opinion'). As will be shown in the following subsections, the fragment usage of the matrix verb with the zero complementizer in other semantic groups of verbs is not as common as is the case with cognition verbs; therefore, verbs of cognition/mental act/propositional attitude can be said to be undergoing a high degree of grammaticalization, as shown in examples (22-24), in which the verbs used as epistemic parentheticals freely occur sentence-medially between pauses ([a] examples) and also sentence-finally after a pause ([b] examples) (Gonzálvez-García (2014) for the discussions of the use of cognition verbs as parentheticals and epistemic markers):

(22) creo 'I think/I believe' as a parenthetical:

a. Les tengo que reportar un evento que, creo yo, denota un cambio importante en el rumbo para varios cientos o miles de pequeños y medianos negocios familiares.

"I have to report an event to them that, I think, denotes an important change in the direction for several hundred or thousands of small and medium-sized family businesses."

(CREA, newspaper, Mexico, 2000)

b. El fútbol me gusta demasiado, creo.

"I like soccer too much, (I) think."

(CREA, newspaper, Costa Rica, 1997)

\section{(23) pienso 'I think' as a parenthetical:}

a. La mujer tiene derecho, yo pienso, al trabajo, y a veces el deber, y además la necesidad en estas épocas, ¿verdad?

"Women have a right, I think, to the job and sometimes the obligation and even the necessity nowadays, right?"

(CREA, oral data; face-to-face conversation/interview, Costa Rica) b. Yo, que nunca he dado gran importancia a los olores, y mucho menos a los perfumes, me dejo impresionar por su aroma. Demasiado dulce, pienso.

"I, who have never given much importance to smells and much less to perfumes, let myself be impressed by her scent. Too sweet, (I) think."

(CREA, novel [María la noche by Ana Cristina Rossi], Costa Rica, 1985)

(24) supongo 'I suppose/I guess' as a parenthetical:

a. [...] desde luego, me gustaba cantar, y quienes me oían lo apreciaban, supongo, pero quienes conozcan mi música en la actualidad acaso se verían sorprendidos.

"[...] of course, I like to sing and those who heard me appreciated it, (I) guess, but those who know my current music, perhaps they would look surprised." (CREA, testimonial [Y si quieres saber de mi pasado by Chavela Vargas], Mexico, 2002)

b. Hay informaciones sociales o políticas que, de ser de dominio público, causarían una desestabilidad mayor, supongo.

"There is social or political information that, being of public domain, would cause a major instability, (I) suppose."

(CREA, newspaper/magazine, Mexico, 1996)

It is also noteworthy that verbs of cognition without a complementizer normally appear with an embedded clause in the indicative mood, not subjunctive, as attested to in all the examples (19-24).

\section{Verbs of Communication}

This section analyzes two verbs of communication commonly found without a complementizer: digo 'I say' and confieso 'I confess'. Table 2 presents the proportions of how many examples of digo 'I say' and confieso 'I confess' take the zero complementizer and the que complementizer in the CREA corpus, limiting the dataset to two countries in order to make the manual counting process manageable. Token frequencies indicated in Table 2 are based on the dataset of Costa Rica (all the data for digo and confieso) and Mexico (partial data including informal and formal registers [oral data, newspaper and magazine] for digo and all the data for confieso). Some of those examples presented in (25-33) include data from countries other than Costa Rica and Mexico for the purpose of illustration. 
Table 2. Distribution of communication verbs with the zero complementizer Vs. the que complementizer in the CREA

\begin{tabular}{lllr}
\hline & Zero complementizer & Que complementizer & Total \\
\hline Digo & $102(37.64 \%)$ & $169(62.36 \%)$ & $271(100 \%)$ \\
Confieso & $12(5.97 \%)$ & $189(94.03 \%)$ & $201(100 \%)$ \\
Total & $114(24.15 \%)$ & $358(75.85 \%)$ & $472(100 \%)$ \\
\hline
\end{tabular}

It is noteworthy that digo 'I say, I mean' appears without a complementizer much more frequently (37.64\%) than confieso 'I confess' (5.97\%). As it will be shown, the sample data from the CREA database suggest that these two verbs behave differently although some similarities are also observed. They are similar in the sense that both verbs (digo and confieso) occur in formal and informal registers as shown in (25-26), respectively. The presence of the clitic pronouns $l e$ 'to you-formal' in $(25 \mathrm{a})$ and te 'to you-informal' in (26a) and (26b) shows whether the contexts are formal or informal:

(25) Formal registers:

a. Sin embargo, habían algunas asignaturas en donde incluso, por ejemplo, las matemáticas que nosotros aprendimos en el liceo, que, le digo, fueron veintiséis años después, las matemáticas que ya se enseñaban en la universidad [...]

"Nevertheless, there were some class subjects in which, for example, even the math that we learned in high school, which, (I) tell you, was the math that was still taught at the university twenty six years later $[\ldots] . "$

(CREA, oral data [face-to-face interview/conversation], Costa Rica, formality = high)

b. A veces, incluso, este agradecimiento se traduce en cartas laudatorias dirigidas a la dirección, o en su materialización en forma de regalos o detalles cuya recepción, confieso, nos producen una honda satisfacción personal.

"Sometimes, even, this appreciation is translated in laudatory letters directed to the direction, or in its materialization in the form of gifts or little presents whose receipt, (I) confess, produces a deep personal satisfaction for us."

(CREA, novel/essay [Memorias de un médico de Urgencias by Luis Jiménez de Diego] Spain, 2002)

(26) Informal registers:

a. Por eso te digo, $\varnothing$ el cubismo es una técnica muy académica.

"For this reason (I) tell you, Ø the cubism is a very academic technique."

(CREA, oral data [conversation], Costa Rica, formality $=$ low) b. $[\ldots]$ en las manifestaciones estudiantiles, bueno, honestamente te confieso, me apasiona cubrir esa parte del periodismo.

"[...] in the student demonstrations, well, frankly (I) confess to you, $\varnothing$ I am passionate about covering this part of journalism."

(CREA, oral data [face-to-face conversation]; Venezuela, formality $=$ low)

Both verbs also occur with an embedded clause in the indicative mood as shown in examples (25-26). However, the verb decir 'to say' can also occur with the subjunctive mood in the embedded clause when the main verb decir denotes a speaker's volition:

(27) Lo que recomiendo es que el pueblo, que es inteligente, vote por la persona más idónea. Yo no le digo $\varnothing$ vote por x o y.

"What I recommend is that people, who are intelligent, vote for the most suitable person. I don't tell you $\varnothing$ vote for x or y."

(CREA, newspaper, Costa Rica, 1996)

In (27), the verb vote appears as the present subjunctive form of votar 'vote' since the main verb digo 'I say' does not convey information as a verb of communication but rather it intends to influence an interlocutor by 'telling him to vote' for someone (acting like a verb of volition) (It may also be interpreted as an imperative in direct speech representation).

Another difference between the two verbs is that digo 'I say' is often used as an epistemic fragment that can freely occur sentence-medially (28) - and also sentence-finally (29) - whereas confieso 'I confess' is not often found in a sentence-final position when it functions as an epistemic adverbial, but does occur sentence-medially (30):

(28) $[\ldots]$ se me hizo bastante difícil, porque, te digo, no tenía clases de dibujo, y [...]

"[...] it seemed to me pretty difficult, because, (I) tell you, I didn't have drawing classes and [...]"

(CREA, oral data [face-to-face conversation], Mexico)

(29) Ya veremos resultados, digo yo.

"Soon we will see results, I say."

(CREA, newspaper, Spain, 1994)

(30) Yo, confieso, no soy una gran relatora de cuentos. 
"I, (I) confess, am not a great storyteller."
(CREA, newspaper, Uruguay, 2001)

When confieso 'I confess' is used as a floated parenthetical in a sentence-final position, it is usually accompanied by the direct object pronoun $l o$ 'it' as in (31-32). In this case, one can say that the verb confesar 'confess' does not function as a true epistemic fragment since the direct object pronoun $l o$ 'it' refers to the entire preceding sentence; it should not be considered as an example of a verb with zero complementizer. It still seems worthwhile to point out that this expression lo confieso 'I confess it (it-I confess)' is prevalent in the sample data collected from the CREA database. Also note that lo confieso 'I confess it (it-I confess)' is commonly observed sentence-medially as well as in (33):

(31) Durante mi juventud, en Holanda, era algo habitual. Me daba rabia, lo confieso.

"During my youth, in Holland, it was something habitual. It infuriated me, (I) confess it." (CREA, newspaper, Spain, 1989)

(32) Fui un borracho, lo confieso. Pero hace rato dejé la bebida.

"I was a drunk, (I) confess it. But I quit drinking a while ago."

(CREA, newspaper, Argentina, 1997)

(33) Yo, lo confieso, no sentí mucha ilusión ante el suceso.

"I, (I) confess it, wasn't thrilled about the happening."

(CREA, essay [Apaga... y vámonos. La televisión: Guía de supervivencia by Joaquín Carbonell, Spain, 1992]

The observations and data analyses so far suggest that it seems reasonable to say that there are clearly some differences between digo 'I say' and confieso 'I confess', especially in terms of the degree of grammaticalization: The verb decir 'say' appears to be used more freely as a reanalyzed semantic unit which expresses the subjectivity of the speaker whereas the verb confesar 'confess' still exhibits some restriction.

\section{Verbs of Volition and Desire}

Verbs of volition and desire are those verbs often cited as complement-taking verbs that can omit the complementizer que and take the embedded clause in the subjunctive. A wide range of verbs appear in the CREA data and this study analyzes the following verbs: esperar 'hope', rogar 'beg', desear 'desire', pedir 'ask', suplicar 'request, beg', solicitar 'request' and recomendar 'recommend'. Table 3 shows the distribution of these volition and desire verbs that take the zero complementizer vs. the que complementizer in the CREA corpus (Mexico and Costa Rica), but the illustrated examples in (34-50) include data from other countries such as Spain.

As will be shown below, this verb group behaves quite differently from verbs of cognition and verbs of communication, in the sense that volition verbs omitting the complementizer (i) typically take the subjunctive in the embedded clause with the exception of esperar 'hope' in certain contexts; (ii) typically (but not exclusively) appear in a formal register; and (iii) are not often used as parenthetical fragments (with the exception of esperar 'hope').

The only verb that seems to appear as a parenthetical fragment is esperar 'hope' as in (34) contrasted by its non-fragment use in (35). It is interesting to note that when esperar 'hope' is used as a parenthetical fragment, the verb in the embedded clause appears in the indicative-typically, a future tense-rather than in the subjunctive, as in (34).

(34) espero 'I hope' as a floated parenthetical/fragment:

a. En fin... son un montón de preguntas vitales para mi existencia que se resolverán, espero, para el jueves.

"In short...they are a lot of vital questions for my existence that will be resolved, (I) hope, by Thursday."

(CREA, Mexico, 2002)

b. Chanes es un loco, murió en el circuito de un problema completamente distinto, que dentro de algunos días estará circulando, espero, por toda la prensa nacional.

"Chanes is a crazy man, he died in a completely distinct ongoing problem, which within a few days will be circulated, (I) hope, by all the national newspapers."

(CREA, novel [Morir en el Golfo by Héctor Aguilar Camín], Mexico, 1986)

(35) espero 'I hope' as a non-fragment:

a. La imagen de Cristo es una copia del famoso escultor danés Thorvaldsen, que espero $\varnothing$ le guste.

"The image of Christ is a copy of the famous Danish sculptor Thorvaldsen, which (I) hope $\varnothing$ you like."

(CREA, novel [El pavo real y la mariposa by Alfonso Chase Brenes], Costa Rica, 1996)

b. Acepto la apuesta, Arturo, y espero $\varnothing$ pagues tú. "I accept the bet, Arturo and (I) hope $\varnothing$ you pay." (CREA, novel [¿Enfermera, doctora o santa? by Rafael Olivera Figueroa], Mexico, 1991) 
Table 3. Distribution of volition and desire verbs with the zero complementizer Vs. the que complementizer in the CREA

\begin{tabular}{llll}
\hline & Zero complementizer & Que complementizer & Total \\
\hline espero & $28(14.43 \%)$ & $166(85.57 \%)$ & $194(100 \%)$ \\
ruego & $44(27.33 \%)$ & $117(72.67 \%)$ & $161(100 \%)$ \\
deseamos $^{l}$ & $3(13.04 \%)$ & $20(86.96 \%)$ & $23(100 \%)$ \\
pido & $20(11.90 \%)$ & $148(88.10 \%)$ & $168(100 \%)$ \\
suplico $^{2}$ & $27(38.57 \%)$ & $43(61.43 \%)$ & $70(100 \%)$ \\
solicito $^{2}$ & $138(56.56 \%)$ & $106(43.44 \%)$ & $244(100 \%)$ \\
recomiendo & $2(9.52 \%)$ & $19(90.48 \%)$ & $21(100 \%)$ \\
Total & $114(24.15 \%)$ & $358(75.85 \%)$ & $472(100 \%)$ \\
\hline
\end{tabular}

${ }^{1}$ The verb deseo 'I desire' can also have a meaning of a noun 'a desire', thus, for the purpose of the data retrieval, the first person plural form of the verb (deseamos 'we desire') was used

${ }^{2} \mathrm{~A}$ high rate of occurrence of solicito is observed in the dataset of Mexico, especially in the formal speech with expressions such as solicito autorice/consulte 'I request (that) you authorize / consult'

In (34), espero 'I hope' is used as a parenthetical which can be interpreted as an adverbial such as con suerte 'hopefully'. Importantly, for this reason, the verbs in the 'embedded' clauses appear in the indicative mood (se resolverán 'they will be solved' and estará 'it will be'), not the subjunctive, since the apparent main verb espero 'I hope' does not really 'govern' the embedded clause to trigger the subjunctive mood. On the other hand, the examples in (35) show that the same verb espero 'I hope' is used as a true matrix verb that triggers the subjunctive mood as in espero (que) le guste 'I hope that you like it' (35a) and espero (que) pagues tú 'I hope that you pay' (35b).

Other volition/desire verbs, on the other hand, typically function as main verbs (with the zero complementizer) that take a true embedded clause - not as floated parentheticals and all the verbs in the embedded clauses appear in the subjunctive as expected. The examples are given in (36-39) below. Note that the first example (36) contains three verbs of volition (pido 'I ask', ruego 'I beg' and ordeno 'I order') without a complementizer, all of which take the subjunctive form of cesar 'to stop' (i.e., cese 'stopsubjunctive. $3^{\text {rd }}$ pers.SG).

(36) ¡En nombre de Dios les pido, les ruego, les ordeno, $\varnothing$ cese la represión!

"In the name of God (I) ask you, (I) beg you, (I) order you, Ø stop the repression."

(CREA, newspaper, Costa Rica, 2003)

(37) Si dije algo que pudiera ofenderles, les suplico $\varnothing$ me disculpen.

"If I said something that could offend you, (I) beg you (that) you forgive me."

(CREA, novel [Regina by Antonio Velasco Piña], Mexico, 1992)

(38) Así también solicito a la Secretaría $\varnothing$ envíe invitaciones oficiales [...]

"In this way (I) also request the ministry (that) they send official invitations [...]"
(CREA, oral data [public speech], Mexico)

(39) Para mayor información de este tema recomiendo $\varnothing$ se lea un libro que se titula [...]

"For more information about this topic (I) recommend (that) one read a book that is entitled $[\ldots]^{\prime \prime}$

(CREA, essay [Lo que el vino se llevó by Armando Barriguete Castellón], Mexico, 1996)

Some of these volition verbs are sometimes used as a 'pseudo-fragment' that appears to be standing alone as a parenthetical, but in fact, with a direct object pronoun $l o$ 'it' which refers to the entire sentence. The examples in (40-41), therefore, do not necessarily represent true cases of parentheticals. We have observed a similar case with the verb confesar 'confess' as in lo confieso 'I confess it':

(40) ¿Y quién será el objeto de mi amor? No te horrorices otra vez, te lo suplico.

"Who will be the object of my love? Don't be terrified again, (I) beg it of you."

(CREA, theater [Las cartas de Mozart by Emilio Carballido], Mexico, 1975)

(41) No vuelvas con él, por favor. Si no quieres hablar de acuerdo pero, te lo ruego, no regreses.

"Don't go back with him, please. If you don't want to talk about an agreement but, (I) beg it of you, don't go back."

(CREA, novel [Días de ira by Jorge Volpi], Mexico, 1994)

Finally, the data from CREA suggest that verbs of volition/desire without a complementizer are used in both formal and informal contexts; however, it seems that the omission of the complementizer que in volition/desire verbs is more common with a formal register rather than with an informal one (cf. Brovetto (2002)). The verb suplico 'request, beg' alone, for 
example, has 27 occurrences in which it appears without the complementizer and among them, 26 examples are used in formal contexts. This is one of the differences that we can observe between volition verbs, on the one hand and cognition verbs and communication verbs, on the other. Recall that cognition verbs and communication verbs with the zero complementizer do not show a particular preference for one register over another (i.e., formal Vs. informal), but the analysis of the data in this study suggests that the volition verb group without a complementizer appears to show a clear preference for a formal register. In the examples below, we can observe examples of volition verbs with the zero complementizer in both formal (42-46) and informal contexts (47-50):

Formal register:

(42) Por favor, le ruego Ø se levante. "Please, (I) beg you (that) you stand up." (CREA, novel [Regina by Antonio Velasco Piña], Mexico, 1987)

(43) $[\ldots]$ nos ha hecho llegar una queja, que deseamos $\varnothing$ sea rápidamente atendida por los servicios sociales $[\ldots]$

"[...] a complaint has arrived to us, which (we) desire (that) it could be attended to promptly by the social services $[\ldots]$ "

(CREA, newsletter, Spain, 1998)

(44) $[\ldots]$ señor Presidente, le pido $\varnothing$ me autorice unos breves minutos para culminar esta exposición.

"Mr. President, (I) ask you (that) you authorize me a few brief minutes to finalize this exposition."

(CREA, oral data [public speech], Mexico, formality $=$ high)

(45) Caballeros, les suplico Ø tengan la bondad de salir de la alberca $[\ldots]$

"Gentlemen, (I) request you (that) you be kind enough to leave the pool [...]."

(CREA, novel [Las rojas son las carreteras by David Martín del Campo], Mexico, 1976)

(46) Le recomiendo $\varnothing$ pase al servicio de otorrinolaringología [...]

"(I) recommend to you (that) you go to the otolaryngology service $[\ldots]$ "

(CREA, novel [¿Enfermera, doctora o santa? by Rafael Olivera Figueroa], Mexico, 1991)

Note that the formal vs. informal registers can be distinguished when there is a clitic pronoun le 'to-you (formal)' as in (42), (44), (45) and (46) and te 'to you (informal)' as in (47-50) (A reviewer mentions that the use of address forms in the Spanish-speaking world is rather complex, thus the presence of the clitic pronouns te Vs. le does not necessarily endorse the informal vs. formal registers, respectively). It should be noted again that the omission of the complementizer is attested in many examples of formal register in the CREA data, but not many examples are found with an informal register.

Informal register:

(47) Es que espera $\varnothing$ te cases con ella tan pronto como el otro sea cliente de funeraria.

"The thing is that (he) hopes $\varnothing$ you marry her as soon as the other guy is a funeral client."

(CREA, novel [El caso 117.720 by Carmen Naranjo], Costa Rica, 1987)

(48) Te ruego $\varnothing$ me acojas en tu revista -fuerte, libre, elocuente- para aclarar algo que [...]

"(I) beg you (that) you accept me in your strong, free and eloquent magazine in order to clarify something that $[\ldots]$ "

(CREA, newspaper, Mexico, 1996)

(49) Y humildemente te pido $\varnothing$ me dejes darte un abrazo de Navidad y otro de agradecimiento.

"And (I) ask you humbly (that) you let me give you a Christmas hug and another for my appreciation."

(CREA, novel [¿Enfermera, doctora o santa? by Rafael Olivera Figueroa, Mexico, 1991)

(50) $[\ldots]$ te solicito $\varnothing$ gires tus apreciables instrucciones a quien corresponda $[\ldots]$

"[...] (I) request you (that) you issue your important instructions to whom it may concern [...]"

(CREA, newspaper, Mexico, 1996)

To summarize, verbs of volition/desire without a complementizer distinguish themselves from verbs of cognition and verbs of communication. While the latter groups of verbs seem to exhibit a higher degree of grammaticalization as shown in many attested examples of verbs used as floated parentheticals, verbs of volition/desire more commonly occur as matrix verbs without a complementizer, which preserves the word order and usual subjunctive form in the embedded clause (i.e., a matrix verb $+(q u e)+$ an embedded clause in the subjunctive).

\section{Verbs of Emotion}

Data for two verbs of emotion that are commonly used without complementizers were extracted mainly from the CREA database of Costa Rica, Mexico and Spain: lamento 'I lament/regret' and temo 'I suspect'/me temo 'I am afraid'. Table 4 shows the distribution of these emotion verbs that take the zero complementizer vs. the que complementizer in the CREA corpus of Costa Rica, Mexico and Spain. 
Table 4. Distribution of emotion verbs with the zero complementizer Vs. the que complementizer in the CREA

\begin{tabular}{llll}
\hline & Zero complementizer & Que complementizer & Total \\
\hline lamento & $4(4.21 \%)$ & $91(95.79 \%)$ & $95(100 \%)$ \\
temo / me temo & $59(7.07 \%)$ & $776(92.93 \%)$ & $835(100 \%)$ \\
Total & $63(6.77 \%)$ & $867(93.23 \%)$ & $930(100 \%)$ \\
\hline
\end{tabular}

These two verbs behave differently in several respects. First of all, very few examples were found for lamentar 'lament' with the zero complementizer (4 occurrences out of 95 examples) when all the datasets from Costa Rica, Mexico and Spain were consulted, as most examples of lamentar appear with other types of complementation such as a noun phrase (e.g., lamento esta debilidad 'I lament this weakness'), a full sentential complement with the complementizer que (e.g., lamento que se vayan 'I lament that they leave') and an infinitival complement (e.g., lamento verte aqui' 'I lament seeing you here'). An example of lamento 'I lament' with the zero complementizer is given in (51):

(51) [...] presentan muy característicos ejemplos a los que lamento $\varnothing$ no se hayan agregado alguno de los últimos de José María Rodríguez Acosta.

"They present very characteristic examples to which (I) lament (that) some of the most recent pieces of José María Rodríguez Acosta were not added."

(CREA, newspaper, Spain, 1991)

The example in (51) shows a non-fragment use of lamentar 'lament', which simply occurs without a complementizer. This verb never seems to occur as a parenthetical at least in the dataset I consulted. In fact, it has been pointed out in Gonzálvez-García (2014) that lamentar 'lament', being a factive verb, does not allow floated parentheticals as shown in (52):

$*$ Que $\quad$ se levante
COMP PASS raise-SBJV.PRS.3SG
la sesión, yo lamento.
the session I regret-PRS.1SG
(example from Gonzálvez-García (2014:189 [11c])

On the other hand, examples of temer without a complementizer were more frequently found in the same dataset (59 out of 835 occurrences [7.07\%]) and it is also encountered as both a main verb (53) and a parenthetical fragment (54):

(53) Anda, apresúrate, ya nos vamos. No llega el español amigo de Don Enrique y yo temo Ø nos hagan antes una visita.

"Come on, hurry up, we are leaving. The Spanish friend of Don Enrique is not arriving and I suspect (that) they will visit us before."
(CREA, novel [Duerme by Carmen Boullosa], Mexico, 1994)-informal register

(54) La fecha, me temo, no es casual [...]

"The date, (I) am afraid, is not by chance [...]"

(CREA, novel [Soldados de Salamina by Javier Cercas], Spain, 2001)

Note, however, that when temer is used as a fragment, it is usually the reflexive construction of temer, that is, temerse 'be afraid-oneself', which is interpreted as 'be afraid'. In such a case, the verb in the 'embedded' clause is in the indicative, as in no es casual 'it is not by chance (no-is. IND.PRES.chance)' in (54) (Note that Temer with a reflexive pronoun (me temo 'I am afraid) is also found once with the subjunctive mood (not the indicative) when it is used as a main verb (i.e., as a non-fragment):

[..] pero me temo Ø no lo vaya aceptar.

"[...] but I am afraid (that) he will not accept it."

(CREA, novel [¿Enfermera, doctora o santa? by Rafael Olivera Figueroa], Mexico, 1991)).

When temer is used as a non-parenthetical fragment, that is, as a main verb as in (53), the subjunctive mood is used as in hagan 'they do.SUBJ.PRES'. In this case, temer without a reflexive pronoun means 'suspect' (For the meaning of temer and temerse, the online dictionary of the Real Academic Española was consulted).

It is noteworthy that when me temo (as a reflexive construction) 'I am afraid' is used as a parenthetical, it normally occurs sentence-medially according to all the examples extracted from the CREA dataset of Costa Rica, Mexico and Spain (55-56), but no example is found with me temo 'I am afraid' appearing sentence-finally. Also note that the expression mucho me temo 'I am very afraid' is found often as a floated parenthetical as in (55):

(55) El resto de la población, mucho me temo, seguirá siendo simple consumidora de las cadenas generalistas.

"The rest of the population, (I) am very afraid, will continue to be a simple consumer of the general chains."

(CREA, newspaper, Spain, 1994) 
(56) Estas últimas, me temo, han de acabar en despotismos militares.

"These last ones, (I) am afraid, will end up in military despotism."

(CREA, essay [De teólogos, pragmáticos y geopoliticos by José Luis Orozco], Mexico, 2001)

In summary, the analysis of the data of the two sample verbs of emotion (lamento 'I lament' and temo/me temo 'I suspect/I am afraid) suggests that the degree of grammaticalization does not appear to be uniform. While lamento 'I lament' without a complementizer is not frequently found in the data, temo/me temo 'I suspect/I am afraid' with the zero complementizer is more commonly found. Moreover, the examples of temo/me temo 'I suspect/I am afraid' show usages of a parenthetical, which suggests some degree of a grammaticalization process with this verb.

\section{Closing Remarks}

I have shown that the zero-complementizer phenomenon in Spanish is quite complex as it involves several interacting factors that can contribute to the likelihood of the omission. It is not necessarily the subjunctive or the irrealis meaning of the embedded clause, nor the formal register that automatically triggers the omission of the complementizer in Spanish. It is rather the semantics of the matrix verb interacting with all those factors that plays an important role in contributing to the omission of the complementizer.

Data analysis has revealed that verbs of cognition such as creo 'I believe', pienso 'I think' and supongo 'I suppose/I guess' omit the complementizer frequently. These verbs are used as a main verb without a complementizer (i.e., non-fragment use), but also as a floated parenthetical that freely occurs sentence-medially and finally. Verbs of communication (digo 'I say' and confieso 'I confess') also exhibit similar behaviors as verbs of cognition, in the sense that they appear as 'complement-introducing main verbs' (i.e., nonparenthetical), but also as a parenthetical that acts like an adverbial occurring sentence-medially (e.g., digo 'I say' and confieso 'I confess') or sentence-finally (e.g., digo 'I say'). I propose, therefore, that both verbs of cognition/mental act and verbs of communication/utterance exhibit a higher degree of a grammaticalization process than other groups of verbs such as verbs of volition/desire (e.g., ruego 'I beg', deseo 'I desire', suplico 'I beg', solicito 'I request') and verbs of emotion (e.g., lamento 'I lament') where most verbs do not tend to stand alone as an adverbial parenthetical when omitting the complementizer. In fact, Kärkkäinen (2003) pointed out in her English data analysis that verbs of cognition such as know, think, believe and remember and utterance verbs such as say "act in the same way as epistemic phrases" since both semantic groups of verbs do not use that as a complementizer and "appear as more or less fixed formulae” (Kärkkäinen, 2003). An 'epistemic phrase', according to Kärkkäinen (2003), may include the following features: (i) Verbs of cognition and perception as well as utterance verbs; (ii) generally a $1^{\text {st }}$ person subject (e.g., I think, I guess); and (iii) generally the present tense of the verb. My Spanish data for verbs of cognition and verbs of communication/utterance also confirm these criteria, thus corroborating the hypothesis that these semantic groups of verbs undergo a high degree of grammaticalization in which verbs without a complementizer are becoming an adverbial that may compete with other existing forms of adverbial expressions such as en mi opinión 'in my opinion' (for creo 'I think', for example). Thus, when there is no complementizer que, the main verb in these semantic groups is reanalyzed as an epistemic discourse marker by language users, which, in turn, can freely occur in positions other than sentenceinitial. This is not always the case for verbs of volition and verbs of emotion. Even among these verb groups, I have also shown that some verbs (e.g., espero 'I hope') tend to appear as a floated parenthetical more frequently than other verbs (e.g., deseo 'I desire'), which suggests a certain degree of the grammaticalization process even if it may not be as obvious as in the cognition and utterance verbs. I propose, therefore, that the degree of grammaticalization differs from verb to verb, as well as from verb class to verb class. This is an ongoing process of language change and, as such, diachronic studies that examine this grammaticalizing construction from the past to the present may be able to provide a picture from a different angle for such a change. In addition, more thorough corpus analyses to find possible factors favoring the omission of the complementizer in Spanish would also help answer some remaining questions for future research.

\section{Acknowledgement}

I would like to thank the two anonymous reviewers for their valuable comments and suggestions. All remaining errors are mine.

\section{References}

Brovetto, C., 2002. Spanish clauses without complementizer. Proceedings of the 29th Linguistic Symposium on Romance Languages, Apr. 8-11, John Benjamins, Amsterdam, Philadelphia, pp: 33-46. DOI: 10.1075/cilt.220.04bro 
Bybee, J., 2006. From usage to grammar: The mind's response to repetition. Language, 82: 529-51. DOI: 10.1353/lan.2006.0186

Bybee, J., R. Perkins and W. Pagliuca, 1994. The Evolution of Grammar: Tense, Aspect and Modality in the Languages of the World. 1st Edn., University of Chicago Press, Chicago, ISBN-10: 0226086658, pp: 398 .

CREA $:<$ http://www.rae.es/recursos/banco-dedatos/crea $>$

Delbecque, N. and B. Lamiroy, 1999. La Subordinación Sustantiva: Subordinadas Enunciativas en Los Complementos Verbales. In: Gramática Descriptiva de la Lengua Española, Bosque, I. and V. Demonte (Eds.), Espasa Calpe, Madrid, pp: 1965-2081.

Demonte, V. and O. Fernández-Soriano, 2009. Force and finiteness in the Spanish complementizer system. Probus, 21: 23-49. DOI: 10.1515/prbs.2009.002

Gonzálvez-García, F., 2014. Bringing Together Fragments and Constructions: Evidence from complementation in English and Spanish. In: Romance Perspectives on Construction Grammar, Boas, H.C. and F. Gonzálvez-García (Eds.), John Benjamins Publishing Company, pp: 181-226.

Kärkkäinen, E., 2003. Epistemic Stance in English Conversation: A Description of its Interactional Functions, with a Focus on I think. 1st Edn., John Benjamins Publishing, ISBN-10: 1588114449, pp: 207.

Kärkkäinen, E., 2007. The Role of I Guess in Conversational Stancetaking. In: Stancetaking in Discourse: Subjectivity, Evaluation, Interaction, Englebretson, R. (Ed.), John Benjamins Publishing Company, pp: 183-219.

Llinàs-Grau, M. and J. Fernández-Sánchez, 2011. Complementizer deletion structures: Against a romance-english unified account. Research report GGT-2011-05, Universitat Autònoma de Barcelona.

Poplack, S., J.A. Walker and R. Malcolmson, 2006. An english "like no other"?: Language contact and change in Quebec. Canad. J. Linguist., 51: 185-213. DOI: $10.1353 /$ cj1.2008.0015

Posio, P., 2011. Spanish subject pronoun usage and verb semantics revisited: First and second person singular subject pronouns and focusing of attention in spoken Peninsular Spanish. J. Pragmat., 43: 777-798.

DOI: $10.1016 /$ j.pragma.2010.10.012

Posio, P., 2013. The expression of first-person-singular subjects in spoken Peninsular Spanish and European Portuguese: Semantic roles and formulaic sequences. Folia Linguist., 47: 253-291.

DOI: 10.1515/flin.2013.010
Posio, P., 2014. Subject expression in grammaticalizing constructions: The case of creo and acho 'I think' in Spanish and Portuguese. J. Pragmat., 63: 5-18. DOI: 10.1016/j.pragma.2013.07.001

Thompson, S.A., 2002. "Object complements" and conversation towards a realistic account. Stud. Lang., 26: 125-163. DOI: 10.1075/s1.26.1.05tho

Thompson, S.A. and A. Mulac, 1991. The discourse conditions for the use of the complementizer that in conversational English. J. Pragmat., 15: 237-251. DOI: 10.1016/0378-2166(91)90012-M

Torrego, E., 1983. More effects of successive cyclic movement. Linguistic Inquiry, 14: 561-565.

Torres-Cacoullos, R., 2011. Variation and Grammaticalization. In: The Handbook of Hispanic Sociolinguistics, Diaz-Campos, M. (Ed.), WileyBlackwell, pp: 148-167.

Torres-Cacoullos, R. and J.A. Walker, 2011. Collocations in Grammaticalization and Variation. In: The Oxford Handbook of Grammaticalization, Narrog, H. and B. Heine (Eds.), Oxford University Press, pp: 229-239.

Traugott, E., 1995. Subjectification in Grammaticalisation. In: Subjectivity and Subjectivisation: Linguistic Perspectives, Stein, D. and S. Wright (Eds.), Cambridge University Press, pp: 31-54.

Traugott, E., 2003. Constructions in Grammaticalization. In: The Handbook of Historical Linguistics, Joseph, B. and R. Janda (Eds.), Blackwell, Oxford, pp: 624-47.

Travis, C.E., 2006. Subjetivización de Construcciones: Los Verbos 'Cognitivos' en el Español Conversacional. In: Octavo Encuentro Internacional de Lingüística en el Noroeste, Rosa María Ortiz Ciscomani (Ed.), Universidad de Sonora, Sonora, Mexico, pp: 85-109.

Vázquez Rozas, V., 2006. Construcción Gramatical y Valor Epistémico: El Caso de Supongo. In: XXXV Simposio Internacional de la Sociedad Española de Lingüística, Llamazares, M.V. (Ed.), Universidad de León, Dpto. de Filología Hispánica y Clásica, León, pp: 1888-1900.

Yoon, J., 2004. Infinitival Complement Constructions in Spanish: A Construction Grammar approach. In: Contemporary approaches to Romance linguistics, Auger, J., J.C. Clements and B. Vance (Eds.), John Benjamins Publishing Company, pp: 381-397. 